Огляди літератури, оригінальні дослідження, погляд на проблему

УДК [616.379-008.64: 616.12-008.331.1]: 618.173-078: 57.088: 575.174.015.3

DOI 10.11603/1811-2471.2016.v0.i4.7070

\title{
САG ПОЛІМОРФІЗМ ГЕНА АНДРОГЕНОВОГО РЕЦЕПТОРА У ЖІНОК В ПОСТМЕНОПАУЗІ, ХВОРИХ НА АРТЕРІАЛЬНУ ГІПЕРТЕНЗІЮ ТА ЦУКРОВИЙ ДІАБЕТ
}

@Т. С. Бутова

\section{Харківський національний медичний університет}

РЕЗЮМЕ. Дослідити зв'язок між САG-повторами гена $A R$ та рівнем дигідротестостерону (ДГТ) у сироватці крові у жінок у постменопаузі (ПМ), хворих на цукровий діабет (ЦД) 2 типу та артеріальну гіпертензію (АГ).

106 жінок у ПМ були поділені на групи: до 1 входило 30 хворих на ЦД 2 типу; до 2 - 34 хворих на АГ 2-3 ступеня; до 3-42 хворих на АГ 2-3 ступеня та ЦД 2 типу, до групи контролю - 31 жінка. У всіх жінок імуноферментним способом вимірювали рівень ДГТ в сироватці крові, виділяли геном ДНК з лейкоцитів крові, проводили ідентифікацію кількості САG-повторів у гені $A R$ методом ПЦР.

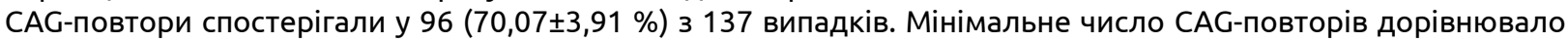
14 , максимальне - 28, поширеність алелів гена $A R$ була достовірно різною залежно від груп пацієнток. 3 метою визначення впливу поліморфізму гена $A R$ на ризик розвитку захворювання було проведено порівняльний аналіз довжини алелей між групами спостереження за допомогою показника SBM. За критичне значення кількості САGповторів було взято 22 повтори. Між показниками рівня ДГТ і САG-повторами серед всіх груп спостерігали прямий кореляційний зв'язок.

АГ як супутня хвороба негативно впливає на перебіг ЦД 2 типу у жінок у ПМ, що виражається у більшому підвищенні рівня ДГТ у венозній крові у групі хворих з коморбідною патологією, ніж у хворих на ЦД 2 типу.

Виявлено зв'язок між рівнем ДГТ у плазмі крові та кількістю САG-повторів у жінок у ПМ, більш сильний кореляційний зв'язок був між ДГТ і «довгими» алелями гена $A R$ у групі з коморбідною патологією (АГ з ЦД 2 типу).

Наявність збільшеної кількості CAG-повторів у гені $A R$ можна розцінювати як предиктор розвитку та прогресії АГ у жінок з ЦД 2 типу у ПМ.

КлЮчОВІ СлОВА: артеріальна гіпертензія, цукровий діабет, поліморфізм гена $A R$, дигідротестостерон, постменопауза.

Вступ. Сучасна жінка майже третину свого життя проводить у стані дефіциту статевих гормонів [1]. У цей період серцево-судинні захворювання (ССЗ) стають провідною причиною захворюваності і смертності серед жінок. Найнебезпечнішим $\epsilon$ поєднання артеріальної гіпертензії (АГ) і цукрового діабету (ЦД), яке, порівняно з чоловіками, збільшує ризик смертності у жінок у 2 рази [2].

Численні дослідження довели гендерні відмінності у розвитку та перебігу низки захворювань $[3,4]$. Європейське ендокринологічне суспільство ставить акцент на вивчення впливу андрогенів на здоров'я жінки у різні періоди ії життя [5]. Відомо, що андрогени у жінок в постменопаузний період чинять на організм як пряму, так i опосередковану естрогенами дію, вони важливі для сталого стану жіночого здоров'я [6].

Андрогени впливають на організм людини через зв'язування зі своїм специфічним рецептором. Тож одним із актуальних механізмів на сьогодні, які обумовлюють відмінності у реалізації біологічних ефектів андрогенів, $\epsilon$ поліморфізм CAGповторів гена рецептора андрогенів, що обумовлює чутливість рецепторів до дії даних гормонів. Ядерний андрогеновий рецептор (АР) розташований на клітинах-мішенях різних тканин: АР містяться у клітинах судин, сім'яників, простати, шкіри, клітинах нервової та інших тканин і найбільше активізуються під дією дигідротестостерону (ДГТ), який утворюється у результаті тканинного метаболізму тестостерону та $\epsilon$ біологічно найактивнішим андрогеном. Геномні ефекти андрогенів обумовлені алельними варіантами поліморфізму коротких повторювальних послідовностей першого екзону гена рецептора андрогенів $(A R)$ за кількістю CAG-повторів: цитозин-аденін-гуанін повторів. У нормі у представників європеоїдної раси у гені АР 20-26 САG-повторів [7, 8]. Алелі із частотою 9-35 повторів розглядають як ризик розвитку патології, але вони можуть зустрічатись і у здорових людей. Алелі з числом повторів більше 38 патогенетичні для всіх носіїв: у пацієнтів розвиваються нейром'язова патологія (спінальна бульбарна м'язова атрофія та ін.) [9]. Існує зворотна залежність між кількістю САG-повторів і активністю АР: зі збільшенням числа повторів спостерігається зменшення функціональної активності АР $[10,11]$. Ген рецептора андрогену $A R$ міститься у Х-хромосомі, тобто має X-зчеплений тип наслідування. Таким чином, жінки можуть мати як один варіант гена (гомозиготи), так і 2 різних варіанти САG-повторів (гетерозиготи) [12].

Мета дослідження. Дослідити зв'язок між CAG-повторами гена $A R$ та рівнем ДГТ у сироватці крові у жінок у постменопаузі, хворих на цукровий діабет 2 типу та артеріальну гіпертензію.

Матеріал і методи дослідження. У дослідженні взяли участь 106 жінок, які перебували на 
Огляди літератури, оригінальні дослідження, погляд на проблему

лікуванні в ендокринологічному та кардіологічному відділенях К3О3 «Обласна клінічна лікарня - центр екстреної медичної допомоги та медицини катастроф" м. Харкова.

Обстежені жінки перебували в ранній природній постменопаузі, не мали тяжких супутніх нефропатій, гострих серцево-судинних захворювань, порушень мозкового кровообігу, гострих запальних та загострення хронічних запальних захворювань, онкологічної патології, токсичних та вірусних гепатитів, алергічних реакцій, тютюнової та алкогольної залежності.

Пацієнти були поділені на групи: до 1 входили хворі на цукровий діабет 2 типу (30 пацієнток); до 2 - хворі на АГ 2-3 ступеня (34 пацієнтки); до 3 - хворі на АГ 2-3 ступеня та ЦД 2 типу (42 пацієнтки). До групи контролю входила 31 жінка в ранній природній постменопаузі, 3 відсутністю ендокринних захворювань, нормальним артеріальним тиском та рівнем глікозильованого (глікованого) гемоглобіну НbA1c<6\%.

Усі жінки проживали у одній місцевості. На момент обстеження пацієнтки, які мали захворювання на ЦД 2 типу, перебували в стадії субкомпенсації, субоптимального глікемічного контролю (НbА1c<7,5\%). Жінки з АГ мали рівень глікозильованого (глікованого) гемоглобіну $\mathrm{HbA1c<6 \% .}$ Групи були зіставні за віком, віком настання менопаузи, тривалістю постменопаузного періоду, індексом маси тіла (IMT). Замісну гормональну та гіполіпідемічну терапію пацієнтки до госпіталізації та включення у дослідження не отримували. Впродовж лікування у стаціонарі пацієнтки отримували терапію згідно з діючими клінічними протоколами.

Вік обстежених пацієнток варіював в діапазоні 45-60 років. Дані про вік настання природної менопаузи, тривалість періоду постменопаузи отримали зі слів пацієнток. Тривалість постменопаузального періоду була від 2 до 6 років (табл. 1). Усім пацієнткам визначали вміст фолікулосимулювального гормону (ФСГ) у сироватці крові імуноферментним методом з використанням набору реактивів для імуноферментного дослідження фірми «ХЕМА» (Російська Федерація). Менопаузу діагностували при рівні ФСГ більше 25 МОд/мл.
Діагноз ЦД 2 типу встановлювали відповідно до класифікації порушень глікемії (WHO, 2006 [13] та наказу МОЗ України № 1118 від 22.12.2012). Верифікацію артеріальної гіпертензії проводили згідно з рекомендаціями Європейського товариства з ведення артеріальної гіпертензії (ESH) та Європейського товариства кардіологів (ESC) (2013) [14], рекомендацією Української асоціації кардіологів (2008) [15] та наказом МОЗ України № 384 від 24.05.2012. Артеріальна гіпертензія у досліджуваних пацієнток викликана гіпертонічною хворобою (ГХ) ІІ стадії 2-3 ступеня. Стадію ГХ встановлювали за класифікацією, розробленою експертами ВООЗ (1963-1993), прийнятою в Україні у 1992 р. згідно з Наказом МОЗ України № 206 від 30.12.1992 і рекомендованою до подальшого застосування.

Рівень дигідротестостерону в сироватці венозної крові вимірювали імуноферментним способом з використанням набору для імуноферментного дослідження фірми «DRG International InC» (USA).

Геномну ДНК виділяли з лейкоцитів венозної крові за допомогою набору реактивів NeоРгер100 DNA (набір фірми NEOGENE (Україна)). Ідентифікацію кількості CAG-повторів у 1 екзоні гена $A R$ проводили методом ПЦР за допомогою набору реактивів фірми NEOGENE (Україна). У нашому дослідженні, згідно з інструкцією до набору, у нормі довжина ампліфікованої ділянки 227-245 пар основ (20-26 САG-повторів відповідно).

Частоту алелів, що зустрічаються, обчислювали шляхом прямого підрахунку за формулою: $\mathrm{F}=\mathrm{n} / 2 \mathrm{~N}$, де $\mathrm{n}-$ кількість випадків виявлення алеля у дослідній групі (у гомозигот алель враховувався двічі); N - число досліджених зразків.

3 метою визначення впливу поліморфізму гена $A R$ на ризик розвитку захворювання було проведено порівняльний аналіз довжини алелів у групах. Для цього було досліджено частоту поширення алелів гена $A R$ та частоту SBM (simple biallelic mean), показника середнього біалельного значення, який визначається як середнє арифметичне кількості САG-повторів обох алелів.

Фактичний матеріал опрацьовано на персональному комп'ютері за допомогою аналізу бази

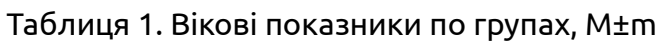

\begin{tabular}{|l|c|c|c|c|}
\hline \multirow{2}{*}{\multicolumn{1}{|c|}{ Показник }} & \multicolumn{3}{|c|}{ Групи } \\
\cline { 2 - 5 } & $\begin{array}{c}1 \\
\text { (хворі на ЦД) }\end{array}$ & $\begin{array}{c}2 \\
\text { (хворі на АГ) }\end{array}$ & $\begin{array}{c}3 \\
\text { (хворі на ЦД та АГ) }\end{array}$ & група контролю \\
\hline Вік, років & $51,43 \pm 0,97$ & $53,36 \pm 0,82$ & $52,05 \pm 0,74$ & $53,77 \pm 0,81$ \\
\hline $\begin{array}{l}\text { Вік настання природної ме- } \\
\text { нопаузи, років }\end{array}$ & $47,53 \pm 1,02$ & $49,26 \pm 0,91$ & $47,79 \pm 0,73$ & $49,23 \pm 0,86$ \\
\hline $\begin{array}{l}\text { Тривалість постменопаузи, } \\
\text { років }\end{array}$ & $3,90 \pm 0,25$ & $4,11 \pm 0,24$ & $4,26 \pm 0,21$ & $4,54 \pm 0,22$ \\
\hline
\end{tabular}


Огляди літератури, оригінальні дослідження, погляд на проблему

даних карт хворих, адаптованих для обробки за програмою Microsoft Excel. Статистичну значущість різниці показників визначали з використанням t-критерію Стьюдента у незалежних групах 3 урахуванням розбіжності у кількості спостережень. Існування лінійної залежності між показниками аналізували за допомогою розрахунку коефіцієнта парної кореляції Карла Пірсона ( $r$ ) [16].

Результати й обговорення. У нашому дослідженні САG-повтори спостерігалися у 96 $(70,07 \pm 3,91 \%)$ з 137 випадків. Мінімальне число CAG-повторів дорівнювало 14, максимальне - 28, але при цьому поширеність алелів гена $A R$ була достовірно різною, залежно від груп пацієнток.

Дослідження зразків ДНК, отриманих від 31 відносно здорової жінки, показало наявність повторів CAG-тринуклеотидів у 29 з 31 випадка. Мінімальне число САG-повторів дорівнювало 17, максимальне - 28. У контрольній групі найпоширеніший алель з 24 САG-повторами був виявлений у 24 (41,38 \%) випадках з 58 (табл. 2).

Ухворих 1 групи повтори САG-тринуклеотидів спостерігалися у 28 з 30 випадків, число CAGтринуклеотидів варіювало від 17 до 27. Найпоширенішим алелем гена $A R$, виявленим у пацієнток 3 ЦД 2 типу, був алель з 20 САG-повторами, він зустрічався в 24 з 56 випадків (табл. 2).

При дослідженні 2 групи (АГ) було виявлено наявність повторів CAG-тринуклеотидів у 31 хворої 34 випадків, прицьомучисло САG-тринуклеотидів варіювало від 18 до 27. Найпоширенішим алелем гена $A R$ було виявлено алель з 25 повторами САG-тринуклеотидів, він зустрічався у 23 з 62 випадків (табл. 2).

У хворих третьої групи (ЦД та АГ) наявність повторів CAG-тринуклеотидів спостерігалося у 37 хворих з 42 відпадків. При цьому максимальне значення CAG-повторів було 26, а мінімальне - 14 . Найпоширенішим алелем гена $A R$ був алель 319 CAG-повторами, він зустрічався у 28 з 74 випадків (табл. 2). На фоні даного розподілу алелів гена андрогенів у жінок 3 групи спостерігалася найвиразніша статистично значуща дигідротестостеронемія серед дослідних груп (табл. 3).

3 метою визначення впливу поліморфізму гена $A R$ на ризик розвитку захворювання було проведено порівняльний аналіз довжини алелів між групами спостереження за допомогою показника SBM (табл. 4). У нашому дослідженні за критичне значення кількості CAG-повторів гена $A R$ було взято 22 повтори.

За допомогою кореляційного аналізу Пірсона виявлено зворотний зв'язок між рівнем ДГТ і кількістю САG-повторів (табл. 5).

Як видно з результатів, представлених у таблиці 5, між показниками рівня ДГТ у сироватці крові і САG-повторами гена андрогенового рецептора у обстежених жінок всіх груп спостерігається прямий кореляційний зв'язок, що свідчить про пряму негативну залежність показника концентрації ДГТ у сироватці крові та довжиною САGповторів гена $A R$ (табл. 5).

Таблиця 2. Розподіл алелів гена $A R$ за кількістю CAG-повторів

\begin{tabular}{|c|c|c|c|c|}
\hline Групи & n & $\begin{array}{l}\text { Кількість випадків } \\
\text { САG-повторів }\end{array}$ & $\begin{array}{c}\text { Варіації } \\
\text { САG-тринуклео- } \\
\text { тидів } \\
\end{array}$ & $\begin{array}{c}\text { Кількість CAG-повторів у } \\
\text { поширенішому алелі (частота } \\
\text { зустрічальності, \%) } \\
\end{array}$ \\
\hline \begin{tabular}{|l|} 
Перша група \\
(хворі на Цд 2 типу)
\end{tabular} & 30 & $\begin{array}{c}28 \\
(93,33 \pm 4,55 \%)\end{array}$ & Від 17 до 27 & 20 у 24 випадках з $56(42,86 \pm 6,61)$ \\
\hline $\begin{array}{l}\text { Друга група } \\
\text { (хворі на АГ 2-3 ступенів) }\end{array}$ & 34 & $\begin{array}{c}31 \\
(91,18 \pm 4,86 \%)\end{array}$ & Від 18 до 27 & 25 у 23 випадках $з 62(37,10 \pm 6,13)$ \\
\hline $\begin{array}{l}\text { Tретя група } \\
\text { (хворі на Цд } 2 \text { типу та АГ } \\
\text { 2-3 ступенів) }\end{array}$ & 42 & $\begin{array}{c}37 \\
(88,10 \pm 5,00 \%)\end{array}$ & Від 14 до 26 & 19 у 28 випадках з $74(37,84 \pm 5,64)$ \\
\hline Група контролю & 31 & $\begin{array}{c}29 \\
(93,55 \pm 4,41 \%)\end{array}$ & Від 17 до 28 & 24 у 24 випадках з $58(41,38 \pm 6,47)$ \\
\hline
\end{tabular}

Таблиця 3. Особливості вмісту дигідротестостерону в крові жінок у постменопаузному періоді

\begin{tabular}{|c|c|c|c|c|}
\hline \multirow{2}{*}{ Показник } & \multicolumn{4}{|c|}{ Групи за результатами обстеження } \\
\cline { 2 - 5 } & $\begin{array}{c}\text { хворі на ЦД 2 типу } \\
(\mathrm{n}=30)\end{array}$ & $\begin{array}{c}\text { хворі на АГ } \\
(\mathrm{n}=34)\end{array}$ & $\begin{array}{c}\text { хворі на ЦД 2 типу та } \\
\text { з АГ }(\mathrm{n}=42)\end{array}$ & $\begin{array}{c}\text { група контролю } \\
(\mathrm{n}=31)\end{array}$ \\
\hline Дигідротестостерон, пг/мл & $75,68 \pm 2,96^{* \bullet}$ & $58,71 \pm 3,78^{* \#}$ & $92,18 \pm 3,36^{*^{\circ}}$ & $44,22 \pm 1,78$ \\
\hline
\end{tabular}

Примітки:

* - p < 0,05 за t-критерієм Стьюдента, порівняння 1, 2 і 3 груп з 4;

- p < 0,05 за t-критерієм Стьюдента, порівняння 1 групи з 2;

- $\mathrm{p}<0,05$ за t-критерієм Стьюдента, порівняння 1 групи з 3;

\#-р < 0,05 за t-критерієм Стьюдента, порівняння 2 групи $з 3$. 
Огляди літератури, оригінальні дослідження, погляд на проблему

Таблиця 4. Оцінка поліморфізму гена андрогенового рецептора

\begin{tabular}{|c|c|c|c|c|c|}
\hline Групи & $\mathrm{n}$ & $\begin{array}{c}\text { Кількість } \\
\text { випадків } \\
\text { CAG-повторів }\end{array}$ & Діапазон SBM & $\begin{array}{c}\text { Середнє зна- } \\
\text { чення SBM }\end{array}$ & $\begin{array}{c}\text { Кількість CAG-повторів } \\
\text { у найпоширенішому алелі (часто- } \\
\text { та зустрічальності, \%) }\end{array}$ \\
\hline $\begin{array}{l}\text { Перша група } \\
\text { (хворі на ЦД } 2 \text { типу) }\end{array}$ & 30 & $\begin{array}{c}28 \\
(93,33 \pm 4,55 \%) \\
\end{array}$ & $19-26,5$ & 21,27 & 20 у 7 випадках з $56(12,50 \pm 4,42)$ \\
\hline $\begin{array}{l}\text { Друга група } \\
\text { (хворі на АГ 2-3 ступенів) }\end{array}$ & 34 & $\begin{array}{c}31 \\
(91,18 \pm 4,86 \%) \\
\end{array}$ & $18-26,5$ & 23,85 & 25 у 7 випадках з $62(11,29 \pm 4,02)$ \\
\hline $\begin{array}{l}\text { Третя група } \\
\text { (хворі на ЦД } 2 \text { типу та АГ } \\
\text { 2-3 ступенів) }\end{array}$ & 42 & $\begin{array}{c}37 \\
(88,10 \pm 5,00 \%)\end{array}$ & $16,5-26$ & 20,43 & 19 у 10 випадках з $74(13,51 \pm 3,97)$ \\
\hline Група контролю & 31 & $\begin{array}{c}29 \\
(93,55 \pm 4,41 \%)\end{array}$ & $18-27,5$ & 23,83 & 24 у 8 випадках з $58(13,79 \pm 4,53)$ \\
\hline
\end{tabular}

Таблиця 5. Показники кореляційного зв'язку дигідротестостерону та довжини CAG-повтору гена AR

\begin{tabular}{|c|c|c|c|c|}
\hline \multirow[t]{2}{*}{ Група } & \multicolumn{2}{|c|}{$\begin{array}{c}\text { Кількість } \\
\text { САG-повторів } \leq 22\end{array}$} & \multicolumn{2}{|c|}{$\begin{array}{c}\text { Кількість } \\
\text { CAG-повторів }>22\end{array}$} \\
\hline & $\Gamma$ & $p(t)$ & $r$ & $p(t)$ \\
\hline 1 & $-0,78$ & $\begin{array}{c}p<0,05 \\
(t=-5,42)\end{array}$ & $-0,96$ & $\begin{array}{c}p<0,05 \\
(t=-9,18)\end{array}$ \\
\hline II & $-0,89$ & $\begin{array}{c}p<0,05 \\
(t=-4,59)\end{array}$ & $-0,95$ & $\begin{array}{c}p<0,05 \\
(t=-14,12)\end{array}$ \\
\hline III & $-0,77$ & $\begin{array}{c}p<0,05 \\
(t=-6,85)\end{array}$ & $-0,97$ & $\begin{array}{c}p<0,05 \\
(t=-8,84)\end{array}$ \\
\hline Група контролю & $-0,98$ & $\begin{array}{c}p<0,05 \\
(t=-9,27)\end{array}$ & $-0,57$ & $\begin{array}{c}p<0,05 \\
(t=-3,40)\end{array}$ \\
\hline
\end{tabular}

Висновки. За результатами проведеної роботи можна зробити висновок, що АГ, як супутня хвороба, негативно впливає на перебіг ЦД 2 типу в жінок у постменопаузний період, що виражається у більш вираженому підвищенні рівня ДгТ у венозній крові у групі хворих з коморбідною патологією, ніж у групі хворих на ЦД 2 типу.

Результати наших досліджень вказують на зв'язок між рівнем ДГТ у плазмі крові та кількістю CAG-повторів у жінок у постменопаузі. Ми спостерігали більш сильний кореляційний зв'язок між ДГТ і «довгими» алелями гена $A R$ у групі з комор- бідною патологією (АГ з ЦД 2 типу). Таким чином, наявність збільшеної кількості САG-повторів у даному гені можна розцінювати як предиктор розвитку та прогресування артеріальної гіпертензії у жінок з ЦД 2 типу у постменопаузі та виокремити групу ризику з метою профілактики розвитку АГ у даної когорти жінок.

Перспективи подальших досліджень. Дослідження зв'язку кількості CAG-повторів гена $A R$ з гормональним, біохімічним складом крові у жінок у ПМ дозволить виділити групу ризику з метою профілактики захворювань.

\section{ЛІТЕРАТУРА}

1. Електронний ресурс. World Health Organization Statistical Information System. 2009. Режим доступу: www.who.int/whosis.

2. The DECODE study group on behalf of the European Diabetes Epidemiology Group. 1999. Glucose tolerance and mortality: comparisonof WHO and American Diabetic Association diagnostic criteria. The DECODE study group on behalf of the European Diabetes Epidemiology Group. Lancet. -1999. - Vol. 354 (9179). - P. 617-621.

3. Ed. by Armen Yuri Gasparya. 2012. Cardiovascular Risk Factors / Gender-Specific Aspects in the Clinical Presentation of Cardiovascular Disease. InTech: Chapter 14. -2012. - 504 p.

4. Butov O. D. Association of interleukins genes polymorphisms with multi-drug resistant tuberculosis in Ukrainian population / O. D. Butov, M. M. Kuzhko, S. T. Butova //

Pneumonologia i Alergologia Polska. - 2016. - Vol. 84, No. 3. - P. 168-173.

5. Androgen Therapy in Women: An Endocrine Society Clinical Practice / M. E. Wierman, R. Basson, S. R. Davis, M. E. Wierman // J. Clin. Endocrinol. Metabol. - 2006. Vol. 91 (10). - P. 3697-3716.

6. Калинченко С. Ю. Роль андрогенов у женщин: что мы знаем? / С. Ю. Калинченко, С. С. Апетов // Леч врач. 2010. - № 8. - C. 78-83.

7. Gao W. Chemistry and structural biology of androgen receptor / W. Gao, C. E. Bohl, Y. T. Dalton // Chem. Rev. -2005. - Vol. 105(9). - P. 3352-3370.

8. Gobinet J. Molecular action of androgens / J. Gobinet, N. Pujol, C. Sultan // Mol. Cell. Endocrinol. - 2002. - Vol. 198. -P. 15-24. 
Огляди літератури, оригінальні дослідження, погляд на проблему

9. Reduced androgen receptor gene expression with first exon CAG repeat expansion / C. S. Choong, J. A. Kemppainen, Z. X. Zhou, E. M. Wilson // Mol. Endocrinol. -1996. - Vol. 10, No. 12. - P. 1527-1535.

10. Effect of a short CAG (glutamine) repeat on human androgen receptor function / D. Ding, L. Xu, M. Menon [et al.] // Prostate. - 2004. - Vol. 58(1). - P. 23-32.

11. Formation of the androgen receptor transcription complex/Y. Shang, M. Myers, M. Brown // Mol.Cell. - 2002. - Vol. 9(3). - P. 601-610.

12. Gelmann E. P. Molecular biology of the androgen receptor / E. P. Gelmann // J. Clin. Oncol. - 2002. Vol. 20(13). - P. 3001-3015.

13. Tsigos C. Management of obesity in adults: European clinical practice guidelines / C. Tsigos, V. Hainer,

A. Basdevant // Obesity Facts. - 2008. - Vol. 1, No. 2. P. 106-116.

14. Журавлева Л. В. Современная стратегия ведения пациентов с артериальной гипертензией / Л. В. Журавлева, Н. А. Лопина // Здоров'я України. - 2014. - № 1 (32). - C. 22-24.

15. Свіщенко $€$. П. Рекомендації Української асоціації кардіологів з профілактики та лікування артеріальної гіпертензії : посібник до Національної програми профілактики і лікування артеріальної гіпертензії (4-е вид.) / Свіщенко Є. П., Багрій А. Е. - К. : ННЦ Інститут кардіології України ім. М. Д. Стражеска, 2012. - 53 с.

16. Лапач С. Н. Статистические методы в медикобиологических исследованиях с использованием Excel / С. Н. Лапач, А. В. Чубенко, П. Н. Бабич - К. : Морион, 2000. $-320 \mathrm{c}$.

\section{CAG POLYMORPHISM RECEPTOR GENE ANDROGENS IN POSTMENOPAUSAL WOMEN WITH HYPERTENSION AND DIABETES}

๑T. S. Butova

\section{Kharkiv National Medical University}

SUMMARY. The aim of the work was to investigate the relationship between repetitions CAG- repeats $A R$ gene and levels of dihydrotestosterone (DHT) in the serum of postmenopausal women (PM), with diabetes mellitus (DM) type 2 and hypertension (HT).

106 women in PM were divided into groups: the first included 30 patients with type 2 diabetes; the second - 34 patients with hypertension 2-3 grade; the 3rd - 42 patients with hypertension of -3 degree and type 2 diabetes, the control group - 31 women. All women ELISA method DHT levels measured in serum isolated genomic DNA from white blood cells, were identified number of repetitions CAG- repeats $A R$ gene PCR.

CAG-repeats were observed in 96 (70.07 $\pm 3.91 \%)$ of 137 cases. The minimum number of CAG-repeats equal to 14 maximum - 28 AR gene allele prevalence was significantly different depending on the groups of patients. To determine the influence of gene polymorphisms $A R$ at risk of developing the disease was a comparative analysis of long alleles between groups monitoring via indicator SBM. For critical number of CAG-repeats were taken 22 repetitions. Among indicators of DHT in serum and CAG-repeats in the $A R$ gene observed groups of women observed a direct correlation.

AG as concomitant disease, adversely affect the course of type 2 diabetes in women PM, resulting in greater levels of DHT increase in venous blood in patients with comorbid disorders than in patients with type 2 diabetes.

The relation between the level of DHT in the blood plasma and the number of CAG-repeats in PM women, a strong correlation was between DHT and "long" alleles $A R$ gene in the group with comorbid disorders (hypertension with type 2 diabetes). The presence of increased number of CAG-repeats in $A R$ gene can be regarded as a predictor of the development and progression of hypertension in women with type 2 diabetes in PM.

KEY WORDS: hypertension, diabetes, polymorphism gene $A R, \mathrm{DHT}$, menopause.

Отримано 5.08.2016 